\title{
Nekroloji:
}

\section{PROF. DR. HANS GUSTAV GÜTERBOCK'UN ANISINA}

\section{TAHSIN ÖZGÜC}

Dil ve Tarih-Coğrafya Fakültesi'nin ilk Hititoloji profesörü Dr. H.C. Hans Gustav Güterbock 24 Mart'ta 91 yaşında Şikago'da vefat etti. Türk Tarih Kurumu'nun şeref üyesi olan H.G. Güterbock 27 Mayıs 1908'de Berlin'de doğdu. Babasının "Alman Doğu Kurumu"nun Genel Sekreteri olması, onun daha gençlik yıllarında eski yakındoğu dillerine, tarihine ilgi duymasının nedeni oldu. Hititoloji, Sumeroloji-Assirioloji öğrenimini zamanmn ünlü bilginleri Prof. Dr. Hans Ehelof, Prof. Johannes Friedrich ve Prof. Benno Landsberger'in yanında tamamlayan H.G. Güterbock, göreve Berlin Müzesi'nde başladı.

1936-1948'de ülkemizin ilk Hititoloji disiplininin bașı olarak, eski Anadolu Tarihi ve kültürleri için çok önemli olan bu bilim dalımm kurulup gelişmesinde, uzmanlarm yetişmesinde, öğretim ve araşurma alanında gerçekleştirilmesi gerekenlerin en çoğunu başarmış ve öğrencilerinin orijinal Hitit tabletlerini yayımlamaya başlamalarımı sağlamıştır. Bir sene Uppsala Üniversitesi'nde misafir profesör olarak görev aldıktan sonra, 1949 'da Şikago Üniversitesi "The Oriental Institute"de göreve başlayan H.G. Güterbock 1976 'da seçkin emeritus profesör oldu.

Fakülte'de B. Landsberger ile sıkı işbirliği içinde, kısa sayılabilecek bir sürede, Hititoloji'nin mustakil bir disiplin olarak gelişmesini, ilk Hititoloji kütüphanesinin kurulmasımı sağlamıștır. Öğrencileri üniversitede, müzelerde görevlendirilmişler, çivi yazılı tablet arşivlerinin sorumluluğunu üstlenmişlerdir. Anadolu Medeniyetleri Müzesi büyük salonunun tertip ve tanzimi, onun eseridir.

Boğazköy kazılarına Hititolog olarak katılmıs, Hitit çivi yazılı metinlerini, hiyeroglif yazıtlı Hitit kral mühürlerini ayıı ciltler halinde yayımlamış, hiyerogliflerin okunmasına, anlaşılmasına büyük katkılarda bulınmuş, bu konuda çalışan bilginler arasında seçkin ve saygun yerin sahibi olmuştur. TTK kazılarında keşf edilmiș hiyeroglifli belgeleri, tam zamanmuda, bilim dünyasuna summuş̧ur. 
O, Hitit kültürünün her alanında yoğunlaşturdığı araşturmalarımı, yani tarihini, dilini, edebiyatını, dinini, mitolojisini, gramerini, kanunlanın, devlet yönetimini, sosyal yapısını, etnik ayrılıkları bütün detay ve özellikleriyle aydınlatan ve yazılı belgelerin ışığında sanat eserlerini yorumlayan ender hititologların başında yerini almıştır. Onun Hititoloji alanında aydınlatmaya çalışmadığı, üzerinde durmadığı bir konu, bir problem yoktur. Meslektaşları Hititoloji disiplinine H.G. Güterbock kadar katkıda bulunmuş bilginlerin az olduğunu, yerinin hititologlar listesinde olduğunu, haklı olarak, vurgulamaktadırlar.

O, üstün araşurıcılığının yanında, kendisini Hititolojiye adamış bir hoca olarak, yaşamının sonuna kadar kendisiyle ilişki kurmuş olan zamanın bütün hititologlarına yapı̆ğı yardımlarını, tavsiyelerini, öneri ve tenkitlerini hiç azaltmamışur. Bugün ondan yararlanma şansına sahip olmuş bilginlerin sayısı azımsanamayacak bir seviyededir.

H.G. Güterbock yaşamının son yıllarını büyük bir projenin gerçekleşmesine "Şikago Üniversitesi Hitit Lugatu Projesine" adamışur. Proje üzerinde çalışan meslektaşları onun katılım va katkılarından övgüyle sözetmektedirler; bu lugat onun en önemli eserlerinden biri olacaktur.

H.G. Güterbock'un yayınları, kendisine 1974 ve 1986 'da armağan edilmiş, iki ciltte derlenmiştir. Türkçe'yi anadili gibi konuşan, yazan hocamızın "Kumarbi Efsanesi" hakkındaki kitabı ayı olarak, değişik konulardaki makaleleri de Kurumumuz dergisi Belleten'de yayımlanmıșur.

Akademi üyelikleri, șeref doktorluklarıyla ödüllendirilmiş olan H.G. Güterbock, Türkiye Bilimler Akademisi'nin şeref üyesi; The British Academy'nin, The American Academy of Arts and Sciences'in, Bayerische Akademie der Wissenschaft'ın üyesi; Uppsala ve Ankara Üniversitelerinin șeref doktorudur.

Mustafa Kemal Atatürk'ün yüzüncü doğum yılı nedeniyle New York'ta "Birleșmiş Milletler Merkezi"nde yapılan toplantıda, H.G. Güterbock'un Ankara'daki profesörlüğü süresince, Atatürk tarafından kurulmuş Türkiye Cumhuriyeti'nde yașadığı mutluluğu hiçbir zaman unutmadığımı vurgulayan sözleri, benim bugün de kulaklarımda yansımaktadır. 